\title{
3. 認知リハビリテーションの立場から
}

東京都リハビリテーション病院 本田 哲三

【はじめに】近年脳外傷リハビリテーション（以下，リハビリ）が注目されているが未解 決の点が多い. 本シンポジウムでは演者がかかわってきた複数のプロジェクトから現状を検 討し課題を提起する。

【認知障害の特徵】脳外傷認知（高次脳機能）障害者は認知障害者全体の $10 \%$ をし, 最 も多い症状は記憶障害 (59\%－重複あり), 以下「行動と情緒の障害」 $(44 \%)$, 注意障害, 失 語症，遂行機能障害だった ${ }^{11}$. 神経心理検査でも記憶障害にくわえ前頭葉障害と聽理解傷害が 著明で易損部位（前／側頭葉）との関連が示唆された ${ }^{21}$.

【リハビリの現状】 演者らの調査 ${ }^{2)}$ でリハビリ病院入院期間は平均 4 ヶ月, プログラムは 身体面中心で PT, OT が週 4 時間, ST 3 時間，心理は 2 時間程度だった。入院中 ADL は 有意に改善していた（FAM 入院時 $115.8 \rightarrow$ 退院時 132.0$)^{2)}$.

【暮しぶり】認知障害を有する脳外傷者は基本的 ADL（食事，トイレ，室内移動）よりも IADL（銀行／役所の仕事，金銭管理など）障害が著しい. 退院後の生活では復職は困難で経 済的保証に欠け ${ }^{1)}$ ，親などの同居家族に養われながらテレビ1)，交友 ${ }^{3)}$ などで過ごす傾向があ る.

【認知リハビリの取り組み】米国では最近 EBM の立場で認知リハビリが再評価されてい る ${ }^{4)}$. 我が国では本格的導入前段階だが，演者らは記憶障害 ${ }^{5)}$, 注意障害 ${ }^{6}$ および遂行機能障 害7)でいずれも一定の効果を確認してきた。

【今後の課題】脳外傷リハビリ発展には以下の点が望まれる.

1）認知リハビリ手法開発と周知：現在我が国ではIMPAIRMENT レベルのアプロー

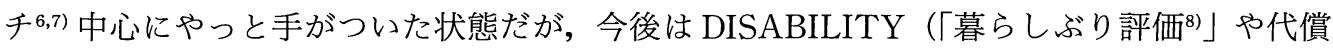
手段の開発など), HANDICAP（制度面の充実一後述）レベルの対応が急務である. 認知障 害は社会生活場面で露呈されやすい傾向がある (前述).したがって ADL 重視の従来のプロ グラムの再検討も要する.

2）制度／体制面の確立：臨床心理士資格制度確立／認知リハビリ保険点数の見直し，認 知障害への (失語と同様) 身体障害としての障害認定制度が望まれる.さらにさまざまな障 害者との交流を通じて障害の自覚と協業を促す「〈身体／精神／知的／高次脳機能障害〉複合 的共同作業所ネットワーク」構想も検討の余地がある，と演者は考えている.

\section{【参考資料】}

1）東京都高次脳機能障害者実態調查研究会：高次脳機能障害者実態調査報告書, 東京都衛生局医療計画 部, 平成 12 年

2）千野直一, 大橋正洋，木村彰男，鹿島晴雄，都丸哲也，本田哲三他：頭部外傷のリハビリに関する研究 班報告書, 同研究班, 平成 11 年

3）本田哲三：当院における頭部外傷者の 10 年間追跡調査一CIQ による研究，東京都リハビリ病院 10 周年 記念報告書, 平成 13 年

4) Cicerone KD, Dahlberg C, Kalmar K, et al. : Evidence-Based Cognitive Rehabilitation : Recommendations for Clinical Practice. Arch Phys Med Rehabil 2000; 81: 1596-1615

5） 本田哲三，鹿島晴雄：記憶障害のリハビリテーション, 脳と精神の医学 $1992 ； 3: 97-101$

6）豊倉穣, 本田哲三他：注意障害にたいする Attention Process Training の紹介とその有効性, リ八医学 $1992 ; 29(2): 153-158$

7）本田哲三，坂爪一幸：遂行機能障害のリハビリテーション，失語症研究 1998；18(2)：146-153

8）水品朋子, 本田哲三他：「暮しぶり評価表」作成の試み, 第 10 回認知リハビリ研究会, 東京, 2000 